Vol. 1 No. 4 Oktober 2021 e-ISSN : 2774-6283 | p-ISSN : 2775-0019

\title{
PENGGUNAAN MEDIA ZOOM MEETING UNTUK MENINGKATKAN MOTIVASI DAN HASIL BELAJAR SISWA KELAS XI UPW1 PADA MATERI FUNGSI KOMPOSISI DI SMK NEGERI 1 BANDUNG
}

\author{
AGUS YAYAT RUHIYAT \\ SMK Negeri 1 Bandung \\ e-mail: agusyayat67@gmail.com
}

\begin{abstract}
ABSTRAK
Penelitian ini adalah penelitian tindakan kelas (PTK) bertujuan untuk Peningkatan Motivasi dan Hasil Belajar Materi Fungsi Komposisi pada siswa kelas XI UPW1 SMKN 1 Bandung dengan menggunakan Media Zoom Cloud Meeting. Berdasarkan dari hasil penelitian dan pembahasan dapatlah disimpulkan bahwa: 1) Penggunaan Media Zoom Meeting dapat Meningkatkan Motivasi belajar Siswa Kelas XI UPW1 Pada Materi Fungsi Komposisi di SMK Negeri 1 Bandung Tahun Pelajaran 2021/2022. Dapat terpantau dari Lembar Observasi berupa angket yang diberikan kepada siswa pada siklus I sebesar $59 \%$ dan siklus II sebesar $81 \%$ menunjukan bahwa siswa termotivasi dalam proses pembelajaran dengan media zoom meningkat. 2) Penggunaan Media Zoom Meeting dapat Meningkatkan Hasil Belajar Siswa Kelas XI UPW1 Pada Materi Fungsi Komposisi di SMK Negeri 1 Bandung Tahun Pelajaran 2021/2022. Mengalami peningkatan pada setiap siklus dengan persentase ketuntasan secara klasikal masing- masing siklus yaitu siklus I sebesar $60 \%$ dan siklus II sebesar $86 \%$.
\end{abstract}

Kata Kunci: Zoom Meeting,Motivasi,Hasil Belajar

\section{ABSTRACT}

This research is classroom action research (CAR) which aims to increase motivation and learning outcomes for the composition function material in class XI UPW1 SMKN 1 Bandung by using Zoom Cloud Meeting Media. Based on the results of the research and discussion, it can be concluded that: 1) The use of Zoom Meeting Media can increase the learning motivation of Class XI UPW1 Students on Composition Function Material at SMK Negeri 1 Bandung in the 2021/2022 academic year. It can be seen from the Observation Sheet in the form of a questionnaire given to students in the first cycle of $59 \%$ and the second cycle of $81 \%$ indicating that students are motivated in the learning process with increasing zoom media. 2) The use of Zoom Meeting Media can Improve Student Learning Outcomes of Class XI UPW1 on Composition Function Material at SMK Negeri 1 Bandung in the 2021/2022 Academic Year. There is an increase in each cycle with the percentage of classical completeness of each cycle, namely the first cycle of $60 \%$ and the second cycle of $86 \%$.

Keywords: Zoom Meeting, Motivation, Learning Outcomes

\section{PENDAHULUAN}

Akibat dari pandemi covid-19 ini, menyebabkan diterapkannya berbagai kebijakan untuk memutus mata rantai penyebaran virus covid-19 di Indonesia. Upaya yang dilakukan oleh pemerintah di Indonesia salah satunya dengan menerapkan himbauan kepada masyarakat agar melakukan physical distancing yaitu himbauan untuk menjaga jarak diantara masyarakat, menjauhi aktivitas dalam segala bentuk kerumunan, perkumpulan, dan menghindari adanya pertemuan yang melibatkan banyak orang. Dengan adanya pembatasan interaksi, Kementerian Pendidikan di Indonesia juga mengeluarkan kebijakan yaitu dengan meliburkan sekolah dan mengganti proses Kegiatan Belajar Mengajar (KBM) dengan menggunakan sistem pembelajaran dalam jaringan (daring) atau pembelajaran jarak jauh (PJJ). Meskipun pembelajaran masih tetap bisa dilakukan tetapi motivasi siswa dalam pembelajaran sangatlah kurang, tentunya ini berdampak pada rendahnya hasil belajar matematika siswa.

Aplikasi Zoom Meeting banyak digunakan sebagai media komunikasi jarak jauh, dengan menggabungkan konferensi vidio pertemuan online, obrolan hingga kolaborasi seluler, seperti 
pada kegiatan pembelajaran atau rapat online, dengan menggunakan aplikasi zoom, ini memungkinkan melakukan meeting sampai 100 partisipan. Melalui aplikasi zoom kegiatan pembelajaran dapat memberikan pengalaman lebih bagi kita, dimana kita bisa berinteraksi secara langsung, melakukan tanya jawab, diskusi dan presentasi tentang masalah yang sedang dihadapi (Noywuli, $(2021 ; 118)$ ).

Menurut Haryono (2016) motivasi belajar merupakan kondisi psikologis untuk dapat menumbuhkan semangat dalam diri, tumbuhnya rasa ingin tahu dan aktif dalam pembelajaran, sehingga dengan adanya motivasi maka peserta didik dapat terdorong untuk belajar lebih serius untuk melakukan sesuatu dan motivasi juga sebagai daya penggerak yang menimbulkan kegiatan belajar, sehingga tujuan belajar yang diharapkan akan tercapai.

Menurut Susanto (Sugiarto, 2020) hasil belajar yaitu perubahan-perubahan yang terjadi pada diri siswa, baik yang menyangkut aspek kognitif, afektif, dan psikomotorik sebagai hasil dari kegiatan belajar, hasil belajar akan menentukan tercapai tidaknya tujuan pendidikan yang diaplikasikan dalam bentuk penilaian dalam rangka memberikan pertimbangan apakah tujuan pendidikan tersebut tercapai. Penilaian hasil belajar tersebut dilakukan terhadap proses belajar mengajar untuk mengetahui tercapainya tidaknya tujuan pengajaran dalam hal penguasaan bahan pelajaran oleh siswa, selain itu penilaian dilakukan untuk mengetahui keefektifan proses belajar mengajar yang dilakukan oleh guru. Dengan kata lain rendahnya hasil belajar yang dicapai siswa tidak hanya disebabkan oleh kurang berhasilnya guru mengajar. Secara sederhana, hasil belajar diartikan sebagai tingkat keberhasilan siswa dalam mempelajari materi pembelajaran.

Dalam pembelajaran di kelas XI UPW1 SMKN 1 Bandung, penulis menggunakan media google classroom, google form dan WhatsApp. Ketika siswa diberikan materi dan tugas pada google classroom dan WhatsApp, hanya beberapa siswa yang termotivasi untuk mengumpulkan tugas pada materi tersebut sebesar $37 \%$. Dan pada saat diadakan evaluasi melalui google form hasil yang di peroleh masih banyak siswa yang memperoleh nilai dibawah ketuntasan sebesar $85 \%$. Rendahnya motivasi siswa dalam pembelajaran juga berdampak terhadap rendahnya hasil belajar siswa ketika diberikan ulangan. Masalah ini tentunya menjadi tantangan bagi guru, bagaimana caranya guru bisa meningkatkan motivasi siswa agar tertarik mengikuti pembelajaran.

Berdasarkan uraian permasalahan di atas, agar siswa tertarik mengikuti pembelajaran dan dapat meningkatkan motivasi dan hasil belajar siswa maka salah satu alternatif solusi yang akan dilakukan adalah dengan menggunakan media zoom meeting dalam pembelajaran, besar harapan siswa dapat berinteraksi dan komunikasi berkaitan dengan materi yang disampaikan pada saat proses pembelajaran berlangsung.

\section{METODE PENELITIAN}

Metode Penelitian yang digunakan adalah metode penelitian tindakan kelas dengan tujuan untuk meningkatan motivasi dan hasil pembelajaran pada materi fungsi komposisi dengan media zoom meeting. Adapun tahapan yang dilakukan nyaitu meliputi kegiatan proses pembelajaran sebagai berikut : Kegiatan awal, peneliti memberikan apersepsi tentang kegiatan pembelajaran yang akan dilakukan dan memberikan motivasi sehingga siswa akan lebih bersemangat dalam mengikuti proses pembelajaran. Pada kegiatan inti, peneliti juga mempersiapkan instrumen angket, lembar evaluasi hasil belajar dan Format Pengamatan. Kegiatan inti, peneliti menyampaikan presentasi materi dan tujuan yang akan dicapai pada pembelajaran hari ini. Siswa menyimak dan berinteraksi dengan guru, baik itu menjawab ataupun bertanya berkaitan dengan materi pembelajaran yang diajarkan melalui zoom meeting tersebut. Dan Penutup, pada kegiatan ini guru mereview dan menyimpulkan keberhasilan pembelajaran yang telah dilaksanakan melalui zoom meeting. Selanjutnya peneliti memberikan Tes Evaluasi Pembelajan dalam bentuk google formulir pada siswa kelas XI UPW1 SMKN 1 Bandung. 
Suharsimi Arikunto (2006:160) menerangkan bahwa instrumen penelitian adalah alat atau fasilitas yang digunakan oleh peneliti dalam mengumpulkan data agar pekerjaan lebih mudah dan hasilnya lebih baik, dalam arti lebih cermat, lengkap dan sistematis sehingga lebih mudah diolah.

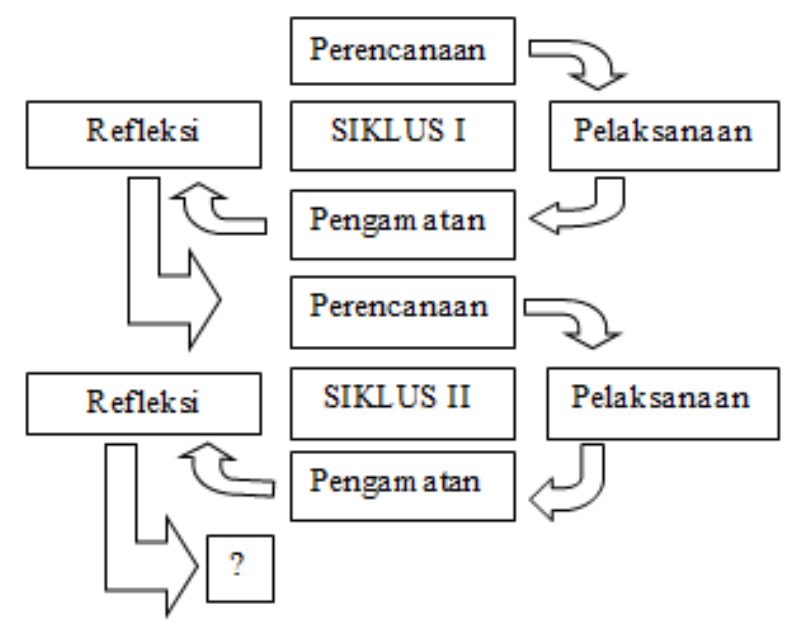

Gambar 1. Tahapan Siklus Penelitian Tindakan Kelas

\section{HASIL DAN PEMBAHASAN}

\section{Hasil}

Berdasarkan dari hasil angket yang telah dibagi kepada 35 siswa diperoleh sebanyak 59 $\%$ siswa suka dengan pembelajaran melalui zoom jadi masih belum cukup optimal dalam motivasi belajar melalui zoom berikut hasil evaluasi belajar sebanyak $60 \%$ yang sudah tuntas secara klasikal. Jadi Refleksi pada siklus ke -1 dari proses pembelajaran yang telah dilakukan oleh peneliti maka pada siklus ke-2 diperlukannya mengubah metode pembelajaran dan memaksimalkan fasilitas zoom meeting dengan melakukan diskusi kelompok melalui breakout rooms. Sedangkan hasil refleksi yang dilakukan pada akhir siklus ke-2, pada proses pembelajaran yang telah dilakukan oleh peneliti maka disimpulkan penggunaan media aplikasi zoom memiliki keberhasilan sesuai dengan indikator yang keberhasilan penelitian. Dari hasil mengumpulan angket yang telah dibagi kepada siswa membuktikan $82 \%$ siswa termotivasi dan merasa tertarik dengan pembelajaran memakai media zoom, dan saat dilaksanakan evaluasi hasil belajar diperoleh $86 \%$ diatas ketuntasan minimal.

Dari hasil penyebaran angket berkaitan dengan motivasi belajar, apakah siswa suka atau kurang suka dalam pembelajaran melalui zoom meeting dimana ini akan menjadi indikator meningkatnya motivasi belajar. Dikatagorikan siswa : Suka yaitu siswa yang memilih jawaban Sangat Suka (SS) dan Suka (S). Kurang Suka yaitu siswa yang memilih jawaban Kurang Suka (KS) dan Sangat Tidak Suka. Dari hasil siklus 1 dan siklus 2 dapat disimpulkan Penggunaan Zoom meeting dapat meningkatkan motivasi pembelajaran sebesar $22 \%$.

Tabel 1. Prosentase Hasil Peningkatan motivasi belajar siswa

\begin{tabular}{|c|l|c|c|}
\hline \multirow{2}{*}{ No } & \multirow{2}{*}{ Siklus } & \multicolumn{2}{|c|}{ Peningkatan motivasi } \\
\cline { 3 - 4 } & & Suka & Kurang Suka \\
\hline 1 & Siklus 1 & $60 \%$ & $40 \%$ \\
\hline 2 & Siklus 2 & $82 \%$ & $18 \%$ \\
\hline & Selisih & $22 \%$ & $28 \%$ \\
\hline
\end{tabular}

Dapat peneliti sampaikan hasil observasi kaitan peningkatan motivasi belajar melalui zoom meeting dilihat dari ketertarikan atau kesukaan peserta didik dalam mengikuti 
pembelajaran didapat disimpulkan pada tabel 1. Ditampilkan prosentase peningkatan motivasi dari siklus 1 pada gambar 1 dan siklus 2 pada gambar 2 dibawah ini

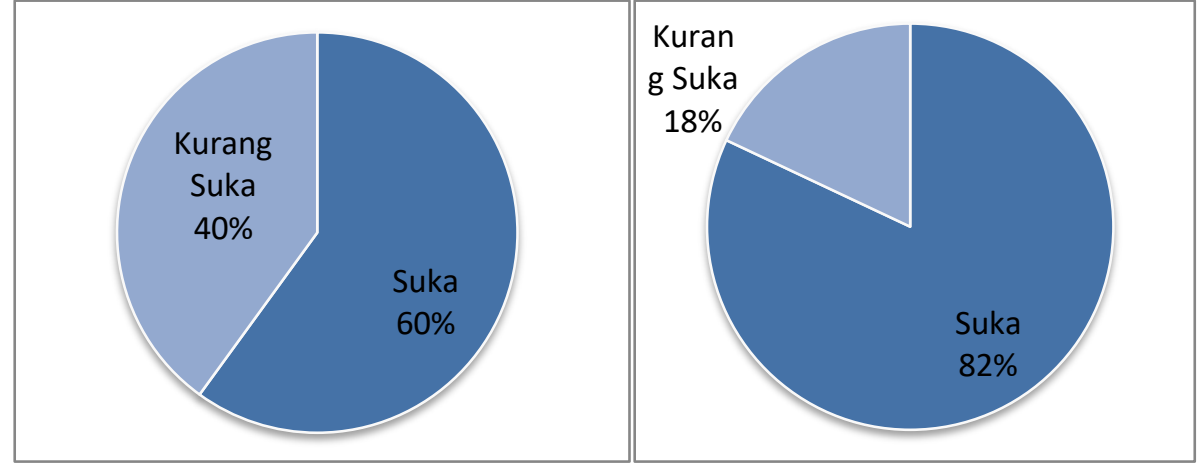

Gambar 1. Prosentase Hasil Observase Motivasi pada siklus I dan II

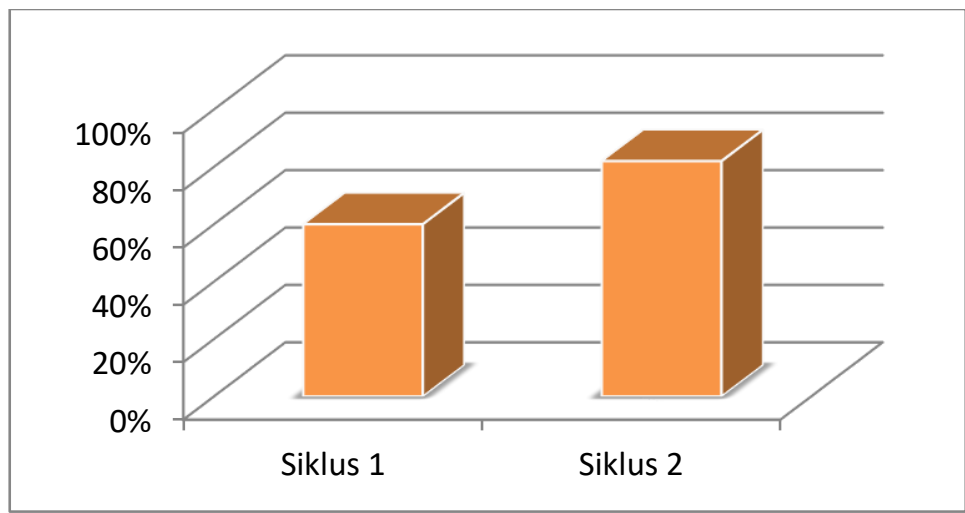

Gambar 2. Prosentasi Peningkatan Motivasi belajar Siklus 1 ke Siklus 2

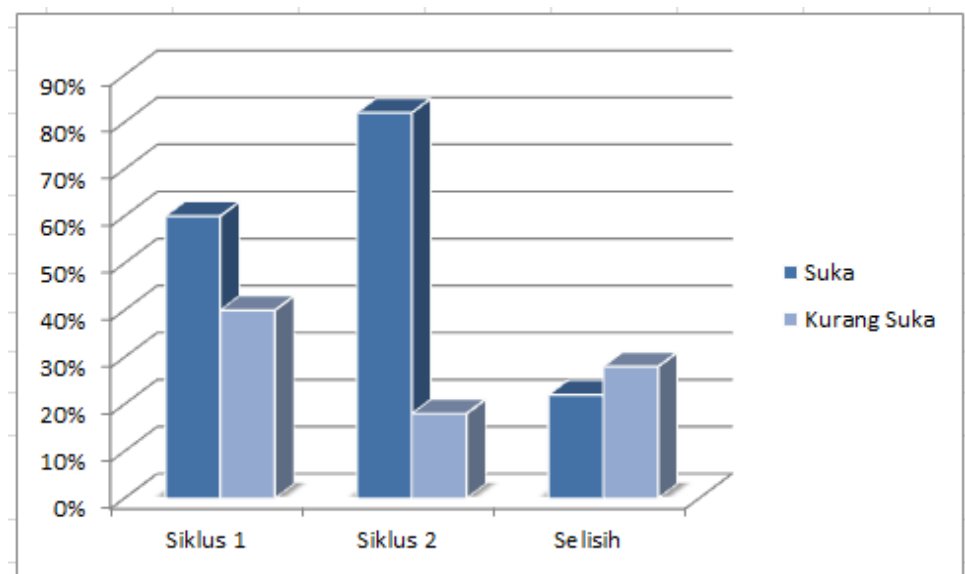

\section{Gambar 3. Grafik Prosentase Peningkatan motivasi belajar siswa}

Hasil belajar dikatakan tuntas apabila siswa telah memperoleh nilai memenuhi KKM $\geq$ 75 (diatas atau sama dengan 75) secara individu, dan nilai hasil belajar meningkat apabila jumlah diatas KKM 80 \% secara klasikal. Dari hasil evaluasi yang dikerjakan siswa pada siklus I diperoleh sebagai berikut tabel 6 . Hasil nya menunjukan yang telah tuntas sebanyak 21 siswa dari 35 siswa jadi baru mencapai $60 \%$. Sementara pada saat evaluasi yang dikerjakan siswa pada siklus II diperoleh sebagai berikut tabel 7. Hasil nya menunjukan yang telah tuntas sebanyak 30 siswa dari 35 siswa jadi baru mencapai $86 \%$.

Dari hasil evaluasi siklus I dan hasil evaluasi siklus 2 pada tabel 2 dapat disimpulkan Penggunaan Zoom meeting dapat meningkatkan hasil belajar sebesar $26 \%$. 
Tabel 2. Prosentase Hasil Belajar siswa

\begin{tabular}{|c|l|c|c|}
\hline \multirow{2}{*}{ No } & \multirow{2}{*}{ Siklus } & \multicolumn{2}{|c|}{ Peningkatan hasil belajar } \\
\cline { 3 - 4 } & & Belum Tuntas & Tuntas \\
\hline 1 & Siklus 1 & $40 \%$ & $60 \%$ \\
\hline 2 & Siklus 2 & $14 \%$ & $86 \%$ \\
\hline & Selisih & $26 \%$ & $26 \%$ \\
\hline
\end{tabular}

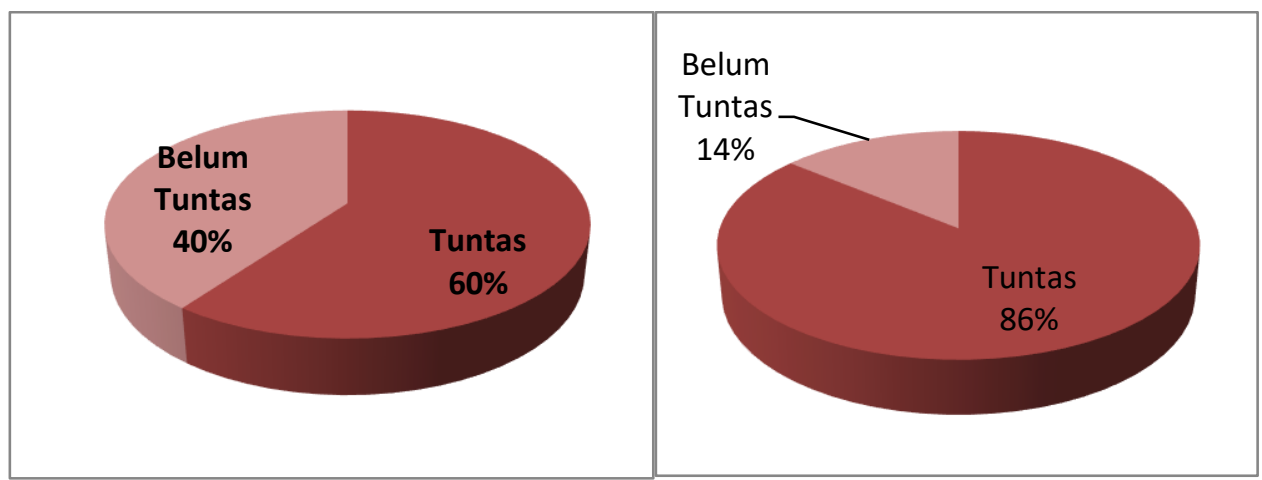

\section{Gambar 4. Grafik Prosentasi Hasil} Belajar pada Siklus 1
Gambar 5. Grafik Prosentase Hasil Belajar Pada Siklus 2

Dari gambar 4 dan 5 perhitungan sebagai berikut :

Prosentasi Hasil belajar Siklus $1: \frac{21}{35} \times 100 \%=60 \%$ ( Nilai diatas KKM)

Prosentasi Hasil belajar Siklus $2: \frac{30}{35} x 100 \%=86 \%$ ( Nilai diatas KKM)

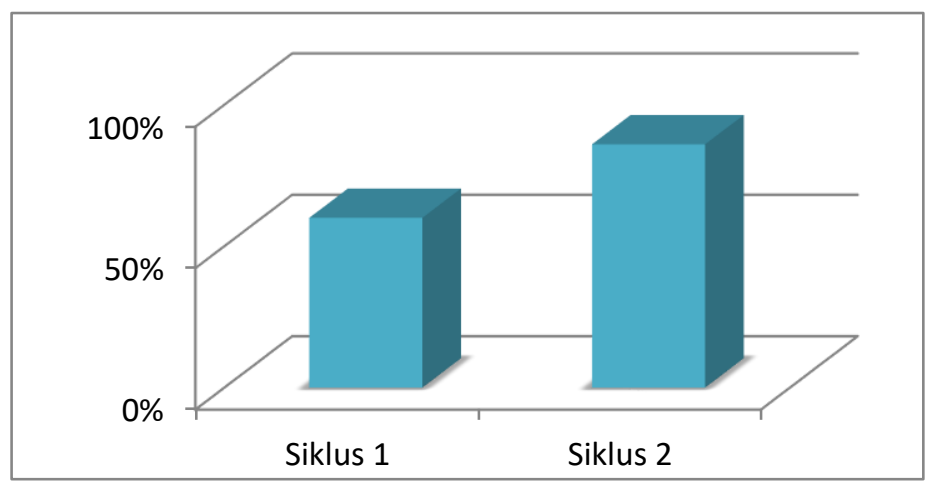

Gambar 6. Prosentasi Peningkatan Hasil belajar Siklus 1 ke Siklus 2

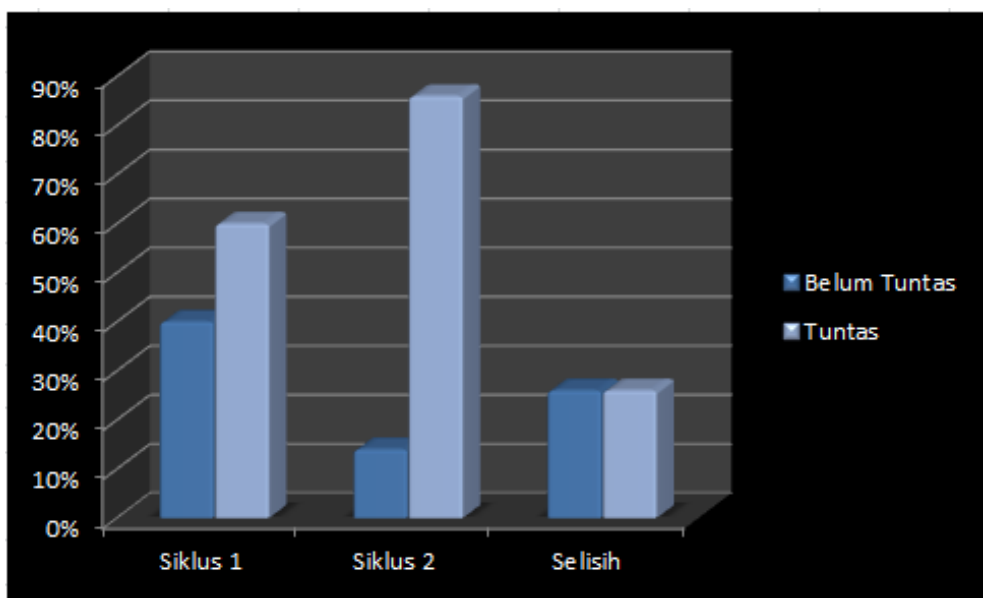

Gambar 7. Grafik Prosentase Peningkatan Evaluasi belajar siswa 


\section{Pembahasan}

Penelitian tindakan kelas ini dilaksanakan sebagai upaya untuk meningkatkan motivasi belajar dan hasil belajar siswa kelas XI UPW1 pada materi Fungsi Komposisi dengan menggunakan media zoom meeting di SMK Negeri 1 Bandung Tahun Pembelajaran 2021/2022. Berdasarkan hasil analisis data pada tiap siklus, terlihat bahwa hasil dari siklus I ke siklus II mengalami peningkatan dari $62 \%$ menjadi $82 \%$, sehingga disimpulkan Penggunaan Zoom meeting dapat meningkatkan motivasi pembelajaran.

Adapun penelitian yang relevan yang dijadikan rujukan peneliti, menurut Saraswati (2022, 65-71) bahwa "Penerapan media zoom meeting dapat meningkatkan motivasi dan hasil belajar IPA pada siswa kelas V SD Negeri Pilangsari 1 Kecamatan Ngrampal Kabupaten Sragen Tahun Pelajaran 2020/ 2021”. Dari Penelitian tentang Penggunaan Media Zoom Meeting ini telah banyak dilakukan oleh guru, sarjana dan dosen. Dan penelitian di atas sejalan dengan penelitian yang dilakukan peneliti yang menyakinkan bahwa Penggunaan Media Zoom Meeting dapat Meningkatkan motivasi dan hasil belajar serta mengilhami dan sekaligus memberikan peta permasalahan yang telah dibahas. Berdasarkan penelusuran atas hasil-hasil penelitian terdahulu, posisi penelitian ini boleh jadi bersifat meneruskan, menyempurnakan, atau membahas yang belum terbahas.

\section{KESIMPULAN}

Berdasarkan hasil penelitian dan pembahasan yang telah diuraikan, maka dapat disimpulkan bahwa : Penggunaan Media Zoom Meeting dapat Meningkatkan Motivasi belajar Siswa Kelas XI UPW1 Pada Materi Fungsi Komposisi di SMK Negeri 1 Bandung Tahun Pelajaran 2021/2022, melalui Lembar Observasi berupa angket yang diberikan kepada siswa pada siklus I sebesar $59 \%$ dan siklus II sebesar $81 \%$ menunjukan bahwa siswa termotivasi dalam proses pembelajaran dengan media zoom meningkat. Dan Penggunaan Media Zoom Meeting dapat Meningkatkan Hasil Belajar Siswa Kelas XI UPW1 Pada Materi Fungsi Komposisi di SMK Negeri 1 Bandung Tahun Pelajaran 2021/2022. Mengalami peningkatan pada setiap siklus dengan persentase ketuntasan secara klasikal masing- masing siklus yaitu siklus I sebesar $60 \%$ dan siklus II sebesar $86 \%$, melalui evaluasi dengan google form.

\section{DAFTAR PUSTAKA}

Daryanto. (2010). Media Pembelajaran. Yogyakarta.Gava Media

Fitria.A. (2014). Penggunaan media audio visual dalam pembelajaran anak usia dini. Cakrawala Dini :Jurnal Pendidikan Anak Usia Dini \& Kerjasama Program Studi PGPAUD UP Kampus Cibiru Bandung \& APG PAUD Indonesia. DOI: https://doi.org/10.17509/cd.v5i2.10498.

Haryono. (2016). Pengaruh Kedisiplinan Siswa Dan Motivasi Belajar Terhadap Prestasi Belajar Siswa Pada Mata Pelajaran Ekonomi. Faktor: Jurnal Ilmiah Kependidikan: Lembaga Penelitian dan Pengabdian Kepada Masyarakat (LPPM), Indonesia. DOI: http://dx.doi.org/10.30998/fjik.v3i3.939

Hermawan, Asep H, dkk. (2009). Media Pembelajaran. Bandung. UPI Pres.

Jalius. J, Ambiyar. (2016). Media dan Sumber Belajar.Jakarta.Kencana.

Magdalena. I. (2021). Tulisan bersama Tentang Media Pembelajaran SD. Sukabumi-Jabar.CV Jejak Anggota IKAPI.

Martini, Noywuli dkk. (2021). Membangun Pembelajaran Merdeka Belajar dan Kampus Merdeka di pergunruan Tinggi-Pemamfaatan Kemajuan Teknologi Melalui Aplikasi Zoom pada Pembelajaran OnLine di PT. Bandung. Penerbit CV. Media Sains Indonesia.

Mulyono. (2013). Pengaruh penggunaan media audio visual pada pembelajaran sholat untuk meningkatkan motivasi belajar peserta didik di Min Beji. Skripsi. Program S1 Fakultas Agama Islam. Universitas Muhammadiyah Sidoardjo.

Pakpahan, dkk. (2020). Pengembangan Media Pembelajaran. Medan. Yayasan Kita Menulis 
Sanaky, AH., Hujair. (2011). Media Pembelajaran Buku Pegangan Wajib Guru dan dosen. Yogyakarta. Kaukaba.

Sugiarto. (2020). Contextual Teaching and Learning (CTL)-Tingkatkan Hasil Belajar Peserta Didik. Yogyakarta. CV Mine.

Wijoyo. H. (2021). Efektifitas Proses Pembelajaran di Masa Pandemi. Sumatra Barat. Insan Cendekia Mandiri. 